\title{
Disease Severity and The Effect of Disease Severity on Quality of Life in Patients with Acne Vulgaris
}

\section{Akne Vulgarisli Hastalarda Hastalık Şiddeti ve Hastalık Şiddetinin Yaşam Kalitesi Üzerine Etkisi}

\author{
(D) Melek Aslan Kayıran, (D) Filiz Cebeci, (D) Ayșe Serap Karadağ, (D) Vefa Aslı Erdemir, (D) Mehmet Salih Gürel \\ İstanbul Medeniyet University, Göztepe Training and Research Hospital, Clinic of Dermatology, İstanbul, Turkey
}

Keywords: Acne vulgaris, psychosocial aspects, quality of life

Anahtar Kelimeler: Akne vulgaris, psikososyal yönleri, yaşam kalitesi

Acne vulgaris is one of the most common diseases affecting the quality of life among skin diseases (1). Studies have shown that patients with acne have high rates of depression, anxiety, suicidal tendency, and negative effects on quality of life have generally been shown to increase with increased acne severity (2). Motley and Finlay (3) from Cardiff University developed "Cardiff Acne Disability Index" (CADI) specifically for patients with acne vulgaris. This index evaluates the findings of how the patient was affected physically, psychologically, emotionally, and socially due to illness. The Turkish version of the CADI form was used in our study (4).

Global Acne Grading System (GAGS), which is used to evaluate clinical severity, is one of the most commonly used scoring systems (5). The study was started following local ethics committee approval (dated 15/12/2016, number: 135).

A total of 202 patients (13-45 years old, 133 female and 69 male) with acne vulgaris were included in the study. Seventy-six patients were under 18 years old and 126 patients were 18 years or older. The mean value of CADI was $6.8 \pm 3.0$ in all patients, $7.1 \pm 3.0$ in females and $6.1 \pm 3.1$ in males. These results showed that CADI was significantly higher in females than males $(p=0.033)$. The mean overall CADI score was $6.3 \pm 3.0$ in female patients under 18 years of age and 7.5 \pm 3.0 in female patients 18 years or older $(p=0.035)$. The mean overall CADI score was $6.6 \pm 2.9$ in male patients under 18 years of age and $5.7 \pm 3.1$ in male patients 18 years and older $(p=0.184)$.

The question indicating how the patient perceived his psychological condition had the lowest mean value with a score of $1.9 \pm 0.8$ and the question asking discomfort due to the presence of acne vulgaris lesions had the lowest mean value with a score of $0.7 \pm 0.9$. The mean score of question asking for the negative emotions and psychological status of the patient due to acne vulgaris was significantly higher in females (mean: 1.5) than in males (mean: 1.2) $(p=0.017)$. Also, the mean score of the question showing how the patient perceived the disease was significantly higher in females (mean: 2.0) than in males (mean: 1.7) $(p=0.028)$. These results showed that women perceived their illness as more severe. The mean score of the question on the negative effects of acne lesions on social life was significantly lower in females under 18 years of age than in females 18 years or older (0.7 vs. 1.1 , respectively, $p=0.017$ ). There was no significant difference between individual questions in terms of gender and age.

There was no significant correlation between age and GAGS score in all patients and in only female patients ( $p=0.183, p=0.214$, respectively). However, GAGS score was significantly higher in male patients under 18 years of age than those aged 18 years and older $(p=0.045)$.

Men had more severe acne vulgaris than women. Regarding age, male patients under 18 years of age had more severe acne vulgaris lesions compared to male patients aged 18 years and older and female patients.

There was no significant correlation between GAGS score and overall CADI score and individual question scores $(p=0.218)$.

Although the severity of acne vulgaris in females was less than in males in this study, it was found that their quality of life was negatively affected and that CADI scores were significantly higher than males. While CADI score was significantly lower in females under 18 years of age than in females 18 years and older, there was no difference in males in terms of age.
This study also presented as poster in 3. National Dermatology \& Cosmetology Congress with International Participants on 14-17 March.

Address for Correspondence/Yazıșma Adresi: Melek Aslan Kayıran, İstanbul Medeniyet University, Göztepe Training and Research Hospital, Clinic of Dermatology, İstanbul, Turkey

Phone: +90 5325232873 E-mail: melekaslan@gmail.com ORCID ID: orcid.org/0000-0003-4347-3134

Cite this article as/Atıf: Aslan Kayıran M, Cebeci F, Karadağ AS, Erdemir VA, Gürel MS. Disease Severity and The Effect of Disease Severity on Quality of Life in Patients with Acne Vulgaris. İstanbul Med J 2019; 20(1): 80-1.

(c) Copyright 2019 by the Istanbul Training and Research Hospital/istanbul Medical Journal published by Galenos Publishing House.

(C) Telif Hakkı 2019 Istanbul Ĕgitim ve Araștırma Hastanesi/Istanbul Tıp Dergisi, Galenos Yayınevi tarafından basılmıștır.
Received/Geliș Tarihi: 08.02.2018 Accepted/Kabul Tarihi: 09.04.2018 
Questionnaire score regarding the effects of acne vulgaris lesions in the body was found to be low in our study. Unlike other studies, the question asked in order to reveal how a person perceives his or her own disease psychologically has the highest mean value in all patients.

In conclusion, although the GAGS score was higher in male patients and males had more severe acne lesions clinically, it was found that female patients were more affected psychosocially and that this effect was more prominent especially in women aged 18 and over regarding CADI scores.

Informed Consent: Written informed consent was obtained from patients who participated in this study.

Peer-review: Externally peer-reviewed.

Author Contributions: Concept - M.A.K.; Design -M.A.K.; Supervision -M.A.K., A.S.K., M.S.G.; Resources - M.A.K., F.C.; Materials - M.A.K., F.C.; Data Collection and/or Processing - M.A.K., F.C.; Analysis and/or Interpretation - M.A.K., V.A.E.; Literature Search - M.A.K., V.A.E.; Writing Manuscript - M.A.K., A.S.K.; Critical Review - M.A.K., A.S.K., M.S.G.
Conflict of Interest: No conflict of interest was declared by the authors.

Financial Disclosure: The authors declared that this study received no financial support.

\section{References}

1. Do JE, Cho SM, In SI, Lim KY, Lee S, Lee ES. Psychosocialaspects of acne vulgaris: a community-based study with Korean adolescents. Ann Dermatol 2009; 21: 125-9.

2. Lukaviciute L, Navickas P, Navickas A, Grigaitiene J, Ganceviciene R, Zouboulis CC. Quality of life, anxiety prevalence, depression symptomatology and suicidal ideation among acne patients in Lithuania. J Eur Acad Dermatol Venereol. 2017; 31: 1900-6.

3. Motley RJ, Finlay AY. Practical use of a disability index in the routine management of acne. Clin Exp Dermatol 1992; 17: 1-3.

4. Atsü N, Seçkin D, Özaydın N, Sanda C, Demirçay Z. Akne hastalarında Cardiff akne kısıtlılık indeksinin Türkçe versiyonunun geçerliliği ve güvenilirliği. Turkderm 2010; 44: 25-7.

5. Doshi A, Zaheer A, Stiller MJ. A comparison of current acne grading systems and proposal of a novel system. Int J Dermatol 1997; 36: 416-8. 